\title{
Metode Anjangsana Pada Komunitas Pemeluk Agama Memupuk Sikap Toleransi Beragama Bagi Kader Perempuan
}

\author{
${ }^{1 *}$ Yuliati Hotifah, ${ }^{2}$ Irene Maya Simon, ${ }^{3}$ Ella Faridati Zen, ${ }^{4}$ Widya Multisari \\ ${ }^{1}$ Jurusan Biologi FMIPA Universitas Negeri Malang; Jalan Semarang 5 Malang \\ ${ }^{2,3,4}$ Universitas Airlangga Surabaya; Jalan Airlangga No. 4-6 Surabaya \\ "Corresponding author: yuliati.hotifah.fip@um.ac.id
}

\begin{abstract}
Abstrak
Kegiatan pengabdian pada masyarakat ini merupakan penerapan metode kearifan lokal yang sudah dilakukan oleh masyarakat Indonesia dalam menumbuhkan sikap saling tolong menolong dan saling hormat menghormati antar sesama.. Mengingat kader perempuan antar umat beragama merupakan figure dan perwakilan dari agamanya masing-masing, maka mereka harus dibekali sikap toleransi beragama yang cukup sebelum mensosialisasikan sikap toleransi beragama kepada umat yang lain. Program kemitraan masyarakat ini ditujukan untuk kader PAUB Kota Malang. Iptek yang diterapkan berupa strategi menumbuhkan sikap toleransi beragama melalui metode anjangsana. Dengan metode anjangsana ini dapat menumbuhkan penghayatan dan praktik kegamaan tidak hanya berhenti pada tahap klaim eksklusifisme (aku) yang berujung pada hubungan personal dengan Tuhan, tidak juga pada tahap inklusifisme (kamu) dengan perhatiannya pada perekrutan dukungan teologis atau ideologis (solidaritas), melainkan juga tahap keterbukaan (kita), dimana penghayatan religius atas nilai-nilai kemanusiaan dapat mewujudkan toleransi beragama tidak hanya pada level wacana. Produk luaran yang dihasilkan berupa modul peningkatan sikap toleransi beragama bagi kader PAUB yang dapat diterapkan pada kader perempuan antar umat beragama di kota-kota lain di Jawa Timur.
\end{abstract}

Kata kunci-Kader perempuan, Metode anjangsana, PAUB, Toleransi beragama.

\begin{abstract}
Community service activities are the application of local wisdom methods that have been carried out by the Indonesian people in fostering mutual assistance to help and respect each other respectfully. Considering women cadres among religious communities are figures and representatives of their respective religions, they sufficient religious tolerance must be provided before socializing the attitude of religious tolerance to other people. This community partnership program is intended for PAUB cadres in Malang. The applied science and technology in the form of strategies to foster an attitude of religious tolerance through the method of Anjangsana. With this method of Anjangsana can foster appreciation and religious practice not only stop at the stage of claims of exclusiveness (I) that lead to a personal relationship with God, not also at the stage of inclusiveism (you) with attention to the recruitment of theological or ideological support (solidarity), but also the stage of openness (us), where the religious appreciation of human values can realize religious tolerance not only at the level of discourse. The output products produced were in the form of modules to increase religious tolerance for PAUB cadres which could be applied to interfaith women cadres in other cities in East Java.
\end{abstract}

Keywords - Female cadres, Anjangsana method, PAUB, religious tolerance

\section{PENDAHULUAN}

$\mathrm{P}$ erempuan antar umat beragama merupakan sebuah organisasi yang terbentuk dari buah kesadaran lintas iman di tahun 1998 oleh berbagai elemen aktifis perempuan di Malang Raya. Dua organisasi perempuan yang memiliki inisiatif untuk membentuk PAUB yaitu aktifis Korp PMII Putri Kota Malang dan Dewan Pembinaan Peran Wanita (DPPW) Gereja Kristen Jawi Wetan (GKJW). Adapun kegiatan yang dilakukan pada saat itu adalah melakukan pengkajian mengenai perempuan dan 


\section{Hotifah dkk. / Jurnal Karinov Vol. 2 No. 3 (2019) 146-151}

agama, merespon sejumlah peristiwa konflik dan kekerasan atas nama agama serta membangun kontribusi meminimalisir terjadinya konflik dan kekerasan.

Tujuan dari terbentuknya PAUB ini adalah membangun komunitas antar iman yang bisa merajut suasana damai, rukun, harmonis dalam cita-cita pluralis untuk bisa menjalin hidup "sehati dalam keperbedaan". Secara khusus, PAUB memiliki visi, terciptanya kerukunan umat beragama yang pluralis melalui gerakan perempuan. Sedangkan misinya dalah menciptakan persaudaraan sejati antar umat beragama melalui penghayatan nilai-nilai agama guna terwujudnya kehidupan yang harmoni, membangun sumber daya manusia perempuan lintas agama berperspektif gender, dan mewujudkan status, peran dan relasi kesetaraan perempuan dan laki-laki.

PAUB di deklarasikan pada tanggal 29 Juni 2002 di Balai Wiyata Gereja Kresten Jawi Wetan. Secara legal formalnya disahkan dengan Akta Notaris no 54 tanggal 24 Pebruari 2004 Oleh Notaris Duri Astuti, SH. PAUB telah menjalin kerjasama dengan berbagai lembaga baik regional, nasional maupun internasional. Hasil jalinan kerjasama itu telah menghasilkan beberapa kegiatan yang diperuntukkan bagi para kader dan anggota perempuan antar umat beragama. PAUB merupakan lembaga organisasi yang cukup strategis, yang terdiri dari berbagai lapisan masyarakat baik dilihat dari segi basik agama maupun pendidikan dan ekonomi. Berdasarkan dasar keagamaan terdiri dari enam agama (Islam, Kristen, Katholik, Hindu, Budha, Konghucu) dan satu aliran kepercayaan. Sedangkan dari segi pendidikan tersebar mulai dari pendidikan SMP sampai pendidikan Doktor. Segi ekonomi juga cukup beragam mulai dari kalangan bawah, menengah dan atas.

Namun, posisi yang strategis ini tidak dibarengi dengan kualitas dan kapasitas para kader perempuan antar umat beragama, mengingat mereka berasal dari latar belakang pendidikan yang sangat beragam. Secara, mereka sebagai pemuka agama yang memiliki kewajiban untuk menyampaikan (dakwah) kepada para umatnya, tetapi di sisi lain, tidak sedikit dari mereka belum memiliki sikap toleransi beragama yang baik. Peningkatan sikap toleransi beragam bagi kader PAUB ini akan memiliki impact yang cukup baik dalam membangun kerukunan antar umat beragama.

Sikap toleransi beragama dapat meningkat dengan cara latihan dan pembiasaan dalam kehidupan sehari-hari. Semakin sering berlatih maka sikap toleransi beragamanya juga semakin meningkat.
Pelaksana kegiatan berpijak pada teori behaviorisme, secara spesifik yaitu hukum exercise (latihan). Berdasarkan teori tersebut, maka perlu diadakan pelatihan sikap toleransi beragama bagi PAUB melalui metode anjangsana. Metode anjangsana yang dimaksud adalah sit in secara singkat kepada komunitas gama-agama secara bergilir, sehingga diharapkan pemahaman yang menyeluruh terhadap agama-agama yang lain tanpa prasangka dan kecurigaan. Secara kuantitas maupun kualitas penguatan kapasitas kader PAUB masih jauh dari sempurna, khususnya sikap toleransi beragama.

Hasil survey menunjukkan bahwa sikap toleransi beragama para kader Perempuan antar umat beragama masih rendah. Sebanyak 40\% kader PAUB masih memiliki sikap toleransi yang rendah selebihnya $60 \%$ tersebar ke dalam dua tingkatan yaitu sedang dan tinggi. Hal ini dikarenakan para aktifis keagamaan yang memiliki waktu dan kesediaan untuk bergabung sebagian besar mereka yang tidak memiliki tugas kantor atau tanggungjawab di instansi, sebagain besar ibu rumah tangga dan para pensiunan.

Fenomena yang sering ditemui saat pertemuan PAUB, adalah sikap toleransi beragam yang masih minim. Hal ini terbukti dari keterbukaan sikap kader yang masih belum maksimal. Di sisi yang lain, pertemuan antar kader yang diselenggarakan masih terbatas waktu sehingga pemahaman atas keberagaman diantara kader belum secara maksimal.

Berdasarkan fenomena di atas, maka menjadi sebuah keniscayaan para kader perempuan antar umat Beragama memiliki sikap toleransi beragama yang baik. Oleh karena itu pengusul mengajukan proposal dalam rangka mengembangkan sikap toleransi beragama melalui metode anjangsana pada komunitas agama-agama.

Berdasarkan uraian analisis situasi di atas, dapat digarisbawahi bahwa masalah mendasar yang dihadapi mitra adalah: rendahnya sikap toleransi beragama bagi kader perempuan antar umat beragama yang berimbas pada terhambatnya tugas dakwah yang menjadi tanggungjawab dalam menyampaikan pesan-pesan moral kepada umatnya/ jamaahnya. Secara garis besar masalah tersebut, dapat dijabarkan sebagai berikut

1. Hanya sekitar $20 \%$ kader yang memiliki sikap toleransi beragama yang bagus. Sebagian besar dari mereka memang memiliki latar belakang pendidikan yang bagus.

2. Sebesar $80 \%$ kader belum memiliki sikap toleransi beragama yang baik, yang dicerminkan 


\section{Hotifah dkk. / Jurnal Karinov Vol. 2 No. 3 (2019) 146-151}

dari tingkat keberhasilan dari dakwah yang disampaikan serta pembauran antar agama.

Atas dasar permasalahan tersebut, maka dibutuhkan metode yang tepat dalam menumbuhkan sikap toleransi antar umat beragama dengan didasarkan pada kearifan lokal setempat. Oleh karena itu tim pelaksana mengangkat judul pengabdian tentang pengembangan sikap toleransi beragama bagi Kader Perempuan Antar Umat Beragama melalui metode anjangsana pada komunitas agama-agama.

\section{METODE}

Masalah yang penting untuk segera ditangani adalah pemahaman pentingnya sikap toleransi beragama bagi kader PAUB secara menyeluruh dan mendalam, hanya $20 \%$ yang memiliki pemahaman tersebut sedangkan sisanya $80 \%$ belum memiliki pemahaman yang cukup. Hal ini dibuktikan dengan pengelompokan berdasarkan agama masing-masing ketika ada kegiatan pertemuan, hal ini menunjukkan bahwa mereka masih belum bisa bergaul dengan nyaman dalam agama yang berbeda-beda.

Untuk itu para kader Perempuan antar umat beragama (PAUB) sangat membutuhkan pembinaan dalam menumbuhkan sikap toleransi beragama. Pembinaan dan pendampingan yang ditawarkan dalam kegiatan pengabdian ini adalah menggunakan prinsip-prinsip pendidikan andragogi, yang disesuaikan dengan karakteristik pendidikan orang dewasa.

Upaya untuk implementasi peningkatan sikap toleransi beragama bagi kader PAUB melalui metode anjangsana dengan pendekatan Epoche. Secara rinci, kegiatan pengabdian masyarakat diuraikan sebagai berikut

\section{a. Kegiatan Anjangsana}

Bentuk kegiatan anjangsana ini dikemas dalam kegiatan kunjung ke komunitas agama-agama, dalam rangka yang pertama adalah menjalin silaturrahmi, dan yang kedua adalah mengenal lebih dalam program dan kegiatan komunitas tersebut. Kegiatan anjangsana dilakukan secara rutin setiap minggu sekali berkunjung ke tempat komunitas agama satu ke komunitas agama yang lain. Komunitas agama yang dituju ada 7 (tujuh) komunitas yaitu komunitas Muslim, komunitas Kristen, komunitas Katolik, komunitas Hindu, komunitas Budha, komunitas Konghucu dan komunitas Aliran kepercayaan.

Kegiatan yang dilakukan di tiap komunitas adalah melakukan FGD dengan pemuka komunitas tersebut. Materi FGD dengan menekankan pada pemahaman saling hormat menghormati antar umat beragama melalui dasar teori Epoché. Epoche pada awalnya digunakan oleh aliran Pyrrhonisme, yakni aliran filsafat Yunani kuno sekitar abad 272 SM, hal ini digunakan untuk mengungkapkan keraguan dalam ilmu pengetahuan, sehingga pendiri dari aliran filsafat tersebut yaitu Pyrrhon, dianggap sebagai pendiri skeptisisme kuno Yunani.

Anjangsana dalam kegiatan ini dilaksanakan secara terjadwal. Kunjungan ke masing-masing komunitas agama bertujuan untuk mengenal lebih dalam tentang kehidupan beragama mereka. Harapannya, dengan memahami lebih dalam, tidak ada prasangka buruk yang terjadi, multiplying impactnya adalah tercipta saling memahami, saling menghormati, terwujudnya sikap toleransi antar umat beragama. Adapun desain kegiatannya berupa forum diskusi saling sharing tentang makna toleransi dari masing-masing agama. Sharing diskusi dikemas dalam forum FGD selama sehari yang dilakukan oleh perwakilan masing-masing komunitas agama-agama. Rincian kegiatannya sebagai berikut

1. Mengirimkan surat permohonan anjangsana kepada tiap komunitas agama (Islam, Kristen, Katholik, Budha, Hindu dan Konghucu)

2. Para kader perempuan antar umat beragama melakukan kunjungan secara terjadwal.

3. Target capaian selama kunjungan adalah pemahaman tentang kehidupan beragama komunitas dan bagaimana pandangan tentang toleransi antar umat beragama

4. Side impactnya adalah merencanakan program bersama dalam membangun kerukunan antar umat beragama

5. Sesi Pengenalan melalui metode Sit In. Pada sesi ini peserta diajak untuk berkeliling area komunitas untuk mengenal lebih dalam situasi peribadatan setiap komunitas. Harapannya dengan kegiatan sit in ini, akan terkurangan kecurigaan dan prasangka terhadap pemeluk agama lain.

\section{b. Analisis dan Sintesis Data Hasil FGD}

Ada tiga tahapan analisis data FGD, yaitu mengkompilasi, analisis, dan sintesis data

1. Kompilasi (compile) yaitu mengumpulkan komentar partisipan ke dalam kolom yang disediakan, yaitu kolom koding, identitas responden dan respon partisipan.

2. Analisis (analyze) yaitu mengkategorikan data yang sudah terkumpul dalam bentuk kategori dengan masukan terbanyak dan kategori dengan masukan terkecil. 


\section{Hotifah dkk. / Jurnal Karinov Vol. 2 No. 3 (2019) 146-151}

3. Sintesis (synthesize), meliputi kegiatan (1) pemberian judul kategori dan sub kategori, (2) menulis atau menandai paragrap pendek yang ditemukan dari tiap sub kategori, dan (3) tambahan catatan penguat pada tiap data fokus grup.

4. Menulis setiap temuan tersebut ke dalam bentuk naratif yang meliputi, laporan eksekutif, latar belakang, metode yang digunakan, bidang temuan, kesimpulan dan rekomendasi.

\section{HASIL DAN PEMBAHASAN}

Anjangsana terhadap komunitas agama-agama yang sudah dilakukan adalah komunitas GKJW, Muslim, GKI, Konghucu dan Budha. Adapun hasil FGD dari kelima komunitas tersebut adalah merumuskan konsep dan pemahamn toleransi antar umat beragama.

Toleransi antar umat beragam memiliki pola dalam menjalin Kerukunan. Menurut hasil FGD dengan para aktifis dan tokoh agama dapat disimpulkan yaitu bagaimana memaknai kerukunan umat beragama dan pluralisme agama. FGD diawali dengan pemantapan terhadap makna kerukunan antar umat beragama, kemudian dilanjutkan topic tentang pluralismen agama.

\section{a. Makna Kerukunan Umat Beragama}

Istilah kerukunan, sebagaimana disebut Imam Syaukani, berasal dari kata "rukun" berarti: baik dan damai, tidak bertentangan; bersatu hati, bersepakat. Merukunkan berarti: mendamaikan; menjadikan bersatu hati. Kerukunan adalah perihal hidup rukun; rasa rukun; kesepakatan: kerukunan hidup bersama. Jadi, kerukunan umat beragama adalah kondisi damai, bersatu hati, atau bersepakat antar pemeluk agama

Menurut PBM No. 9 dan 8 tahun 2006, Bab 1, Pasal 1, kerukunan umat adalah

....keadaan hubungan sesama umat beragama yang dilandasi toleransi, saling mengerti, saling menghormati, menghargai kesetaraan dalam pengamalan ajaran agamanya dan kerja sama dalam kehidupan bermasyarakat, berbangsa dan bernegara di dalam Negara Kesatuan Republik Indonesia berdasarkan Pancasila dan UndangUndang Dasar Republik Indonesia tahun 1945. Bahkan Pemerintah mengembangkan kebijakan trilogi kerukunan, yaitu kerukunan intern umat beragama, kerukunan antarumat beragama, dan kerukunan antar umat beragama dengan pemerintah".

Agama-agama resmi di Indonesia, sebagai subjek dan objek kerukunan, tentunya memiliki pandangan masing-masing tentang kerukunan yang dimaknai oleh ajarannya masing-masing. Dalam Islam, diperintahkan untuk tidak memaksakan orang lain berpindah agama, juga diperintahkan untuk mengajak orang dalam kebenaran dengan cara yang beradab. Selain dari pada itu, orang Muslim juga disuruh untuk berbuat adil kepada seluruh manusia tanpa terkecuali, dengan syarat ia tidak memerangi Islam (Q.S. al-Mumtahanah/60: 8-9).

Dalam Kristen, umatnya diajarkan untuk hidup rukun antar umat beragama, sebagaimana diucapkan oleh Paulus: "Janganlah membalas kejahatan dengan kejahatan, lakukanlah apa yang baik bagi orang lain" (Roma: 12: 17). Hal senada juga telah diucapkan oleh Yesus: "Segala sesuatu yang kamu kehendaki supaya orang berbuat kepadamu, perbuatlah juga demikian kepada mereka" (Matius: 7: 12). Juga dikatakan: Kasihanilah sesamamu manusia seperti dirimu sendiri (Matius: 22: 39). Ajaran Hindu terdapat ajaran Tri Hita Karana. Tri artinya tiga, Hita artinya sejahtera, selamat, rukun, tentram, harmonis. Sementara Karana artinya, pernyebab Hita, yaitu (Pawongan: hubungan yang harmonis antara manusia dan manusia; Palemahan: hubungan yang harmonis antara manusia dengan alam Parhyangan: hubungan yang harmonis antara manusia dengan Tuhan).

Dalam agama Buddha terdapat enam Dharma yang mengarahkan seseorang untuk saling mengingat, saling mencintai, saling menghormati, dan saling menolong. Sedangkan agama Konghucu, terdapat ayat yang mengisyaratkan tentang kerukunan adalah: "seorang susilawan ingin tegak, maka ia juga membantu orang lain tegak dan bila ia ingin maju, maka ia juga membantu orang lain maju." "Saudara saling rukun dalam keluarga akan menentramkan hati orang tua." "Sesuatu usaha itu berhasil dikarenakan mendapat banyak dukungan, sebaliknya gagal dikarenakan kurang mendapat dukungan, dan tiga faktor penentu suatu keberhasilan adalah Tian Se (Kesempatan dan waktu yang tepat)". Ayat-ayat ini mengajarkan bahwa dalam membangun kerukunan antar umat beragama harus dilandasi dengan saling memahami, dan tidak egois.

Pandangan di atas menunjukkan bahwa agamaagama dalam tataran ideal sangat menunjung tinggi toleransi baik secara internal umat beragama maupun antar umat beragama. Hal ini menunjukkan bahwa pada hakikatnya semua agama tidak ada yang 


\section{Hotifah dkk. I Jurnal Karinov Vol. 2 No. 3 (2019) 146-151}

mengajarkan kekerasan (violence), karena fitrah manusia menginginkan hidup damai dan rukun antar sesama.

\section{b. Pluralisme Agama}

Pluralism berasal dari kata plural yang artinya jamak, lebih dari satu (more than one). Pluralism juga dapat diartikan ke dalam dua pengertian. Pertama, pengakuan terhadap keragaman kelompok, baik yang bercorak ras, agama, suku, maupun aliran dengan tetap menjunjung tinggi aspek-aspek perbedaan yang sangat prinsip di antara kelompok-kelompok tersebut Kedua, doktrin yang memandang bahwa tidak ada pendapat yang benar atau semua pendapat adalah sama benarnya. John Hick mendefinisikan pluralisme sebagai berikut

..pluralism is the view that the great world faiths embody different perceptions and conceptions of, and correspondengly different responses to, the real or the Ultimate from within the major variant cultural ways of being human; and that within each of them the transformation of human existence from self-centredness to Reality centredness is manifestly taking place and taking place, so far as human observation can tell to much the same extent [pluralisme agama adalah suatu gagasan bahwa agamaagama besar dunia merupakan persepsi dan konsepsi yang berbeda tentang Yang Real atau Yang Maha Agung dari kultur manusia yang bervariasi; dan bahwa transformasi wujud manusia dari pemusatan-diri menuju pemusatanHakikat terjadi secara nyata dalam kultur manusia tersebut dan terjadi, sejauh yang dapat diamati, sampai pada batas yang sama].

Menurut Nurcholis Madjid, bahwa ada tiga sikap dialog agama yang dapat diambil. Pertama, sikap eksklusif, yaitu sikap yang memandang bahwa agamanya yang paling benar dan yang lain salah. Kedua, sikap inklusif yaitu sikap yang memandang bahwa agama-agama lain adalah bentuk implisit dari agamanya. Ketiga, sikap pluralis, yang memandang agama-agama sama dengan agamanya dan samasama jalan yang sah dalam mencapai kebenaran. Pluralisme agama menurut fatwa MUI adalah suatu paham yang mengajarkan bahwa semua agama adalah sama dan kebenaran setiap agama adalah relatif. Sebab itu, setiap pemeluk agama tidak boleh mengklaim bahwa hanya agamanya saja yang benar sedangkan agama yang lain sesat. Pluralisme agama juga mengajarkan bahwa semua pemeluk agama akan masuk dan hidup berdampingan di surga."
Di Indonesia, paham pluralisme agama setidaknya merujuk pada dua aliran. Pertama, teologi global (Global Theology) lahir dari globalisme Barat. Pengusungnya adalah John Hick seorang teolog Kristen Protestan. Dalam teorinya, Hick merumuskan sebuah revolusi teologis dari pemusatan agamaagama menuju pemusatan tuhan (the transformation from religion-centredness to God-centerdness). Selain itu, Hick juga memandang bahwa agamaagama adalah realitas dari tanggapan budaya manusia yang berbeda-beda dari Satu Yang Nyata (The Real). Dengan teorinya ini, Hick ingin menegaskan bahwa kebenaran agama tidaklah monolitik atau tunggal tapi bersifat plural sesuai dengan jumlah tradisitradisi atau ajaran-ajaran agama yang melaluinya manusia melakukan respons terhadapnya.

Kedua, kesatuan transenden agama (Transcendent Unity of Religion) lahir sebagai kritik terhadap globalisme dan modernitas Barat yang anti agama. Pengusungnya yang terkenal adalah Fritchof Schuon. Ia membagi agama-agama kepada dua hakikat; eksoterik (lahiriah), dan esoterik (batiniah). Dari sudut pandang ini, agama-agama seperti Islam, Kristen, Yahudi, Hindu, dan Buddha merupakan bentuk lahiriah (eksoterik) yang dipisahkan oleh garis horizontal dan bertemu pada hakikat esoterik.

\section{SIMPULAN}

Hasil anjangsana tim pelaksana melalui FGD terhadap beberapa aktifis perempuan antar umat beragama, dapat disimpulkan beberapa poin penting. Pertama, hasil focus group discussion menghasilkan simpulan tentang makna kerukunan umat beragama dan pluralisme agama, kedua tentang pola kerukunan antara umat bergama yang berkembang di masyarakat. Kerukunan antar umat beragama dimaknai sebagai sikap toleransi antar umat beragama. Masing-masing agama dalam tataran ideal sangat menunjung tinggi toleransi baik secara internal umat beragama maupun antar umat beragama. Hal ini menunjukkan bahwa pada hakikatnya agama-agama tidak ada yang mengajarkan kekerasan (violence), karena sesungguhnya fitrah manusia menginginkan hidup damai dan rukun. Sedangkan pluralise agama dapat dimaknai sebagai suatu paham yang mengajarkan semua agama adalah sama dan kebenaran masingmasing agama adalah relatif. Maka setiap pemeluk agama tidak boleh mengklaim bahwa agamanya saja yang benar sedangkan agama yang lain salah. Selain itu juga ditemukan beberapa langkah-langkah teknis kerukunan di Kota Malang, untuk kemudian 
dijadikan dasar dalam melakukan pengabdian lanjutan maupun ditindak lanjuti dengan penelitian terkait dengan kerukunan antar umat beragama demi mempertahankan negara kesatuan republik Indonesia.

\section{DAFTAR RUJUKAN}

Hornby, A.S. (1995). Oxford Advanced Learner's Dictionary. Oxford: University Printing House.

Cassanova, J. (2008). Public Religions In The Modern World. Chicago: Chicago University Press.

Creswell, J.W. (2014). Research Design: Qualitative, Quantitative and Mixed Methods Approaches: fourth edition. Sage publications, Inc.

Eliade, M. (1959). The Sacred and The Profan. New York.

Elmen, P. (2012). The Restoration of Meaning to Contemporary Life. New York: Garden City

Flood, G. (2013). Beyond Phenomenology: Rethinking The Study of Religion. London: Bloomsbury Academic.

Hidayat, K. (2003). Menafsirkan Kehendak Tuhan. Bandung: Mizan.

Kinloch, G. C. (2005). Sociological Theory: Development and Major Paradigm. Bandung: Pustaka Setia.

Lindbeck, G. A. (1985). The Natural Of Doctrine: Religion and Theology in a Post Liberal Age. Philadelphia: The Westminster Press.

Marty, M. E. (2004). When Faiths Collide. New York: Blackwell Publishiers.

Moran, D. (2012). Introduction To Phenomenology. New York.

Niebuhr, R. (1998). The Tolerance and Intolerance In Early Judiasm and Christianity. cambridge: Cambridge Universdity Press.

Parekh, B. (2005). Rethinking Multiculturalism; Cultural Diversity and Political Theory. New York: Palgrave Macmilla.

Proctor, J. D. (2005). Science, Religion and the Human Experience. New York: Oxford University Press. 